\title{
삼킴곤란의 접근
}

\author{
박무인
}

고신대학교 의과대학 내과학교실

\section{Approach of Dysphagia}

\author{
Moo In Park
}

Department of Internal Medicine, Kosin University College of Medicine, Busan, Korea

Dysphagia has been reported to be relatively common and seems to be increased in Korea. Dysphagia can be classified as oropharyngeal dysphagia or esophageal dysphagia. In patients with swallowing difficulties, it is important to determine whether the dysphagia is oropharyngeal or esophageal. Patients with orophayngeal dysphagia are likely to develop aspiration and aspiration pneumonia, so accurate diagnosis should be made in the early stages of complaining of swallowing difficulties. Patients with orophayngeal dysphagia complained difficulty initiating a swallow. Swallowing may be accompanied by coughing, choking, nasopharyngeal regurgitation, aspiration, and a sensation of residual food remaining in the pharynx. Patients with esophageal dysphagia complained difficulty swallowing several seconds after initiating a swallow and a sensation of food getting stuck in the esophagus. Esophageal dysphagia should be characterized by analyzing whether foods that cause swallowing difficulties are solid, liquids or both, whether symptoms are progressive or intermittent, how severe, and associated symptoms, such as weight loss, heartburn, or regurgitation. The approach to diagnostic testing to determine the cause of esophageal dysphagia is based upon the medical history. If esophageal motility disorder is suspected, barium esophagogram is performed first, and upper endoscopy is performed first if structural abnormalities are suspected. If an upper endoscopy shows normal findings, but the esophagus is still suspected of mechanical obstruction, a barium esophagogram is performed. Esophageal manometry should be performed in patients with swallowing difficulties who are suspected of esophageal motility disorder or have normal findings in upper endoscopy. (Korean J Gastroenterol 2021;77:57-63)

Key Words: Dysphagia; Oropharynx; Esophagus; Diagnosis; Swallowing

\section{서 론}

삼킴곤란(dysphagia)은 일반 성인 인구의 $3 \%$ 에서 경험하 는 비교적 흔한 증상이며, ${ }^{1}$ 즉각적으로 정확한 원인 규명과 함께 적절한 치료를 시작해야 하는 경고 증상이다. ${ }^{2}$ 구조적 혹은 운동 기능의 이상으로 인하여 입에서 위로 유동식 혹은 고형식의 음식물의 이동이 원활하지 않을 수 있다. ${ }^{2}$ 환자들은 삼킴의 시작이 되지 않다고 하거나 식도에서 위로 음식이 통 과할 때 장애를 느낀다고 호소하기도 한다. 삼킴곤란은 노화
현상은 아니므로 삼킴곤란의 발생 시 반드시 원인 질환에 대 한 진단 과정을 시작해야 한다. ${ }^{3}$ 본고에서는 삼킴곤란을 호소 하는 환자들에서 정확한 원인 진단을 위하여 어떻게 접근해야 되는지에 대하여 기술하고자 한다.

\section{본 론}

\section{1. 삼킴곤란의 정의}

삼킴곤란은 삼키는 데 어려움이나 이상을 느끼는 주관적

Received January 22, 2021. Revised February 15, 2021. Accepted February 22, 2021.

(C) This is an open access article distributed under the terms of the Creative Commons Attribution Non-Commercial License (http://creativecommons.org/licenses/ by-nc/4.0) which permits unrestricted non-commercial use, distribution, and reproduction in any medium, provided the original work is properly cited.

Copyright (c) 2021. Korean Society of Gastroenterology.

교신저자: 박무인, 49267 , 부산시 서구 감천로 262 , 고신대학교 의과대학 내과학교실

Correspondence to: Moo In Park, Department of Internal Medicine, Kosin University College of Medicine, 262 Gamcheon-ro, Seo-gu, Busan 49267, Korea. Tel: +82-51-990-6719, Fax: +82-51-990-5055, E-mail: mipark@ns.kosinmed.or.kr, ORCID: https://orcid.org/0000-0003-2071-6957

Financial support: None. Conflict of interest: None. 
증상이다. 삼킴곤란은 삼킴의 시작부터 이상이 발생한 구인두 삼킴곤란(orophayngeal dysphagia)과 입에서 위까지 유동식 혹은 고형식의 이동이 원활하지 않다고 느끼는 식도 삼킴곤란 (esophageal dysphagia)으로 나눌 수 있다. 연하통(odynophagia) 은 삼킬 때 통증을 느끼는 것을 말하며, 인두구(globus)는 통증 이 수반되지 않는 목구멍의 지속적 혹은 간헐적인 이물감으로 정의된다. ${ }^{4}$ 증상은 갑상선 연골과 복장패임 사이의 중간에 발생 하며 삼킴곤란이나 연하통이 수반되지 않으면서 흔히 먹거나 삼키면 호전된다. 인두구(globus)는 구조적인 이상이나 위 입 구 반(gastric inlet patch), 위식도 역류 질환 혹은 주요 식도운 동 장애가 없을 때 진단된다. ${ }^{5}$

급성 삼킴곤란이란 갑자기 유동식과 고형식을 포함하는 음 식물이나 침을 삼키지 못하게 되는 경우를 가리키는데, 성인 에 있어서 흔한 원인은 음식 박힘(food impaction)이다. 대 개 쇠고기, 닭고기 등을 먹은 후, 고깃덩어리가 식도내강을 막아서 발생하며 침을 뱉어내는 증상이 발생한다. 음식 박힘 은 성인에서 연간 10 만 명당 25 명 정도 발생하고 남성에서 여성보다 약간 더 많으며, 나이가 증가할수록 빈도는 증가하 며 특히 60대 이후에 많이 발생한다. ${ }^{6,7}$

\section{2. 삼킴곤란의 역학}

삼킴곤란은 비교적 흔한 증상으로 보고되고 있으며 50세 이상의 성인들의 $8-22 \%$ 에서 발생한다. ${ }^{8-12}$ 호주 요양원에서의 삼킴곤란의 유병률은 40-60\% 정도로 추정된다. ${ }^{13}$ Mayo Clinic에서 이루어진 일반 인구를 대상으로 한 우편 설문지 연구에서 삼킴곤란의 유병률은 $7 \%$ 였으나., ${ }^{14}$ 위험인자에 대한 분석은 없었다. 2015년에 Mayo Clinic에서 발표한 연구에 따 르면, 7,640명의 일반 인구를 대상으로 한 우편 설문 연구에 서 지난 1 년간 일주일에 한 번 이상의 삼킴곤란이 있었던 경 우가 약 $3 \%$ 였고, 성별, 나이에 따른 차이는 없었다. ${ }^{1}$ 프로톤펌 프억제제 사용, 가슴 쓰림과 산역류 등의 증상과 높은 신체화 점수 등이 삼킴곤란과 연관성이 있었다.

우리나라의 요양원 환자들을 대상으로 한 연구에서는 $52.7 \%$ 의 유병률을 보였다. ${ }^{15}$ 최근에 우리나라에서 이루어진 건강보 험심사평가원에서 제공하는 청구 데이터 중 2007년 1월 1일 부터 2017년 12월 31일까지 총 11년 동안 연하장애 질환으로 의료기관을 내원한 입원 및 외래 환자를 대상으로 한 후향적 코호트 연구에서 연하장애의 조유병률은 2007년에 인구 10만 명당 635.4명(0.635\%)에서 2017년에 1,031.6명(1.032\%)으로 증가하였다. ${ }^{16}$

\section{3. 삼킴곤란의 원인}

삼킴곤란의 원인이 무엇인지 알고자 하는 경우에는 증상이 인두나 상부식도 혹은 식도체부나 식도위 접합부에서 발생하
였는지 감별하는 것이 중요하다. 그렇지만 많은 질환들이 구 인두 삼킴곤란과 식도 삼킴곤란을 중복해서 일으킬 수 있다는 것을 알고 철저한 병력청취와 약제력의 조사가 이루어져야 한 다(Table 1)

1) 구인두 삼킴곤란(oropharngyeal dysphagia)

젊은 성인에서는 주로 근육 질환, 식도막(esophageal web) 혹은 식도고리(esophageal ring)에 의하여 발생한다. 노인에서 는 뇌졸중(stroke), 파킨슨병, 치매 등의 중추신경계 질환에 의하여 대개 발생한다. 구인두 삼킴곤란이 기계적 폐색으로 인해서인지 신경근육 장애에 의한 것인지 우선 감별해야 한다. 기계적으로 폐색을 일으킬 수 있는 질환들은 인두후농양 (retropharyngeal absecess) 등의 감염, 갑상선종대(thyromegaly), 림프절병(lymphadenopathy), 젠커게실(Zenker diverticulum), 윤상인두 이완불능증(cricopharyngeal achalasia), 근육염과 섬유화 등으로 인한 근육 탄성의 감소, 호산구성 식도염 (eosinophilic esophagitis), 두경부암과 수술과 방사선 치료 후 합병증, 경추 골증식(cervical osteophytes), 구인두 종양

Table 1. Common Causes of Oropharyngeal Dysphagia and Esophageal Dysphagia

\begin{tabular}{|c|c|}
\hline Orophayngeal dysphagia & Esophageal dysphagia \\
\hline Mechanical causes & Intraluminal causes \\
\hline Infections & Foreign bodies \\
\hline Thyromegaly & Mediastinal diseases \\
\hline Lymphadenopathy & Tumors \\
\hline Zenker diverticulum & Infections \\
\hline Reduced muscle compliance & Cardiovascular diseases \\
\hline Head and neck cancers & Mucosal diseases \\
\hline Cervical osteophytes & Peptic stricture \\
\hline Oropharyngeal neoplasms & Esophageal rings and webs \\
\hline Neuromuscular disturbances & Esophageal tumors \\
\hline CNS diseases & Chemical injury \\
\hline \multirow[t]{10}{*}{ Contractile disturbances } & Radiation injury \\
\hline & Infectious esophagitis \\
\hline & Eosinophilic esophagitis \\
\hline & $\begin{array}{l}\text { Tumor or granulation } \\
\text { overgrowth in } \\
\text { esophageal stenting }\end{array}$ \\
\hline & Neuromuscular diseases \\
\hline & Achalasia \\
\hline & $\begin{array}{l}\text { Scleroderma, mixed } \\
\text { connective tissue } \\
\text { disease }\end{array}$ \\
\hline & Jackhammer esophagus \\
\hline & Postsurgical \\
\hline & $\begin{array}{l}\text { Fundoplication and } \\
\text { anti-reflex devices }\end{array}$ \\
\hline
\end{tabular}


등이다. ${ }^{17}$ 신경근육장애들로는 중추신경계 질환인 뇌졸중, 파킨 슨병, 뇌신경마비(cranial nerve palsy), 연수마비(bulbar palsy) 와 근위축측삭경화중(amyotrophic lateral sclerosis) 등과 수 축 장애인 중증근육무력증(myasthenia gravis)과 눈인두근육 디스트로피(oculopharyngeal muscular dystrophy) 등이 있 다. ${ }^{17}$

뇌졸중 발병 3일 내에 환자의 약 $50 \%$ 에서 구인두 삼킴곤 란이 발생하고 이 중 절반에서 흡인이 동반되며 약 $30 \%$ 에서 폐렴이 발생한다. ${ }^{18}$ 그러므로 뇌졸중 환자에서 삼킴곤란의 동 반 유무를 알아보는 것은 폐렴 등의 합병증의 발생을 예방하 기 위해서 아주 중요하다. 파킨슨병 환자의 $50 \%$ 정도까지 구 인두 삼킴곤란과 연관된 증상이 발생하며 약 $95 \%$ 의 환자에서 비디오 투시장치 삼킴 검사(video fluoroscopic swallowing study)에서 이상 소견을 보인다. ${ }^{19,20}$ 구인두 삼킴곤란은 파킨 슨병 초기에도 나타날 수 있지만 대부분 파킨슨병이 진행된 시점에 발생한다.

\section{2) 식도 삼킴곤란(esophageal dysphagia)}

식도 삼킴곤란을 일으키는 원인은 크게 강내 원인(intraluminal causes), 종격 질환(mediastinal diseases), 점막 질환(mucosal diseases), 신경근육 질환(neuromuscular diseases)과 수술 후 합병증 등의 다섯 가지로 나눌 수 있다. 강내 원인은 이물질에 의한 급성 삼킴곤란을 들 수 있고, 종격 질환으로는 폐암, 림프종 등의 종양, 결핵 같은 감염, 심방 확장 혹은 확장된 혈관에 의한 압박 등이 있다. 점막 질환은 염증, 섬유화와 종양 등이 관강을 협소화시켜서 삼킴곤란을 유발하게 되는데, 위식도 역류 질환의 합병증인 소화성 협착(peptic stricture), 식도고리와 식도막, 식도 종양, 부식제 섭취, 약제, 경화요법으로 인한 식도 손상, 방사선 식도염, 헤르페스 바이러스 등의 식도 감염, 호산구 성 식도염, 식도 스텐트 바깥으로 향한 종양의 증식 등이 있다. 신경근육 질환으로는 식도이완불능증(achalasia), 경피증 (scleroderma), 혼합결합조직병(mixed connective tissue disease), 식도 경련(esophageal spasm)과 jackhammer 식도 등이 있고, 위바닥주름술(fundoplication) 후 발생하는 경우도 있다.

미국의 한 기관에서 발표된 후향적 연구 ${ }^{21}$ 에서 1999년부터 2009년까지 삼킴곤란으로 위 내시경을 시행한 1,371명의 환 자에서 삼킴곤란의 원인 질환의 유병률과 그 추이를 분석하였 다. 위식도 역류 질환과 호산구성 식도염의 유병률이 각각 $27.6 \%$ 와 $7.7 \%$ 로 가장 흔한 원인 질환이었다. 10 년간의 추이 를 보면 위식도 역류 질환의 유병률은 $39.3 \%$ 에서 $24.1 \%$ 로 감소한 반면 호산구성 식도염은 $1.6 \%$ 에서 $11.2 \%$ 로 증가하였 다. ${ }^{21}$ 아시아에서 발표된 연구들에 의하면 식도 삼킴곤란의 흔 한 원인들은 식도편평상피세포암, 식도이완불능증과 수술과
관련된 협착 등이었다. ${ }^{22,23}$ 우리나라를 포함한 아시아에서 위 식도 역류 질환의 유병률은 증가하고 있다고 여겨지나 아직도 서구에 비해서 드물다고 할 수 있다.

\section{4. 구인두 삼킴곤란과 식도 삼킴곤란의 감별}

삼킴곤란을 호소하는 환자를 평가하는 첫 단계는 삼킴곤란 이 구인두성인지 식도성인지 감별하는 것이다. 구인두 삼킴곤 란 환자는 흡인과 흡인성 폐렴의 발생 가능성이 높기 때문에 삼킴곤란을 호소하는 경우에 초기에 정확한 진단을 해야 한 다. 폐렴으로 입원한 36명의 70세 이상 노인 환자에서 대조군 과 비교한 연구에서 구인두 삼킴곤란이 지역사회 폐렴의 위험 도를 12 배 증가시켰다. ${ }^{24}$ 관찰 연구들을 체계적으로 분석한 연구에서도 뇌졸중 환자들에서 삼킴곤란이 있을 때 폐렴의 위 험도가 3.17배(RR 3.17, 95\% CI, 2.07-4.87) 증가하였다. ${ }^{25}$

삼킴곤란을 호소하는 경우에 증상에 대한 자세한 병력청취 를 통하여 구인두 삼킴곤란과 식도 삼킴곤란을 감별할 수 있 다. 구인두 삼킴곤란 환자들은 삼킴의 시작이 잘 되지 않거나 증상의 위치를 목 부위로 인식하거나 삼킴시 코인두 역류, 흡 인, 인두에 음식이 남아 있는 느낌을 호소한다. 또한, 침흘림 (drooling), 음식 흘림(food spillage), 침과다증(sialorrehea), 찔끔찔끔 삼킴(piecemeal swallow)과 구음장애(dysarthria) 등의 구강 장애와 기침, 음식 삼킴 시 기도폐쇄(choking)와 발성장애(dysphonia) 등의 인두 증상을 호소한다. 반면 식도 삼킴곤란 환자들은 삼킴 시작 수초 후에 삼키기 어렵다고 하 며 먹은 음식이 식도 상부에서 위 사이에 정체된 느낌을 호소 한다. 환자들이 폐색이 된 위치를 가리킬 때 병변의 위치와 일치하지 않을 수 있다. 한 전향적인 연구에서 26 명의 식도하 부 점막고리(mucosal ring) 환자 중 12명이 삼킴곤란이 있었 는데, 이 중 7명(84\%)에서 목 주위에 폐색감을 호소하였다. ${ }^{26}$ 다른 연구에서는 삼킴곤란을 호소하는 환자 139명에서 전향 적으로 위 내시경을 시행하여 병변의 위치와 환자가 폐색을 호소하는 부위의 연관성을 알아보았다. $74 \%$ 의 환자에서 어느 정도 비슷하였는데 $15 \%$ 에서는 식도 하부에 병변이 있으면서 식도 상부 쪽에 폐색감이 있다고 한 반면, 단지 5\%에서만 식 도 상부에 병변이 있으면서 식도 하부 쪽에 폐색감이 있다고 하였다. ${ }^{27}$ 이런 연구 결과들을 근거로 환자가 흥골 뒤에 폐색 감을 호소하면 병변의 위치와 거의 일치한다고 생각할 수 있 고, 목 쪽에 폐색감을 호소하면 병변의 위치는 목 쪽이 아닐 가능성이 있음을 인식해야 한다. ${ }^{2}$

뇌졸중, 두경부암, 두부, 경부 혹은 경추 수술, 경추 이상, $5,7,9,10,11,12$ 번 뇌신경 이상 등은 구인두 삼킴곤란과 연관이 있을 가능성이 높아서 주의를 요한다. ${ }^{28}$ 파킨슨병과 근 육긴장디스트로피(myotonic dystrophy) 등의 진행성 신경성 질환, 캔디다 감염증과 콜라젠 혈관 질환(collagen vascular 
disorders) 등의 경우에 구인두 삼킴곤란과 식도 삼킴곤란이 함께 발생할 수 있다. ${ }^{29}$ 구인두 삼킴곤란을 진단하기 위하여 간단히 시행할 수 있는 여러 가지 병상 삼킴 검사들(bedside swallowing tests)이 개발되었으며, 이러한 검사들의 진단 민 감도와 특이도는 각각 $70 \%$ 와 $60 \%$ 이상으로 보고되었다. ${ }^{30}$ 최 근에 발표된 캐나다의 가이드라인에서는 삼킴곤란을 호소하 는 환자에서 증상의 분석, 신체 진찰과 병상 삼킴 검사 등을 통하여 구강인두 삼킴곤란을 빠르게 진단하여 흡인이나 흡인 성 폐렴의 위험성을 최소화하도록 권고한다. ${ }^{2}$

\section{5. 삼킴곤란의 진단}

삼킴곤란의 원인 진단을 위해서 제일 중요한 것은 정확한 병력청취다. 철저한 증상의 분석을 통하여 구인두 삼킴곤란과 식도 삼킴곤란의 감별은 대개 가능하다. 식도 삼킴곤란으로 분류된 후 원인 질환의 감별 진단은 삼킴곤란의 양상과 동반 증상 등의 분석으로 이루어지며 원인 질환의 진단을 위하여 위 내시경, 식도조영술과 식도 내압 검사 등을 시행한다(Fig 1). ${ }^{2}$

\section{1) 병력청취}

식도 삼킴곤란을 일으키는 흔한 질환으로는 소화성 협착 (peptic stricture), 식도 종양, 식도고리와 식도막, 식도이완불능 증(achalasia) 등의 다양한 식도 운동 질환들, 경피증(scleroderma), 기능성 삼킴곤란(functional dysphagia)과 방사선 손상 등이 있고, 비교적 드문 질환으로는 림프구성 식도염(lymphocytic esophagitis), 심혈관계 이상, 크론병의 식도 침범과 부식제 손상 등이 있다. ${ }^{31}$

(1) 삼킴곤란 증상의 특징

삼킴곤란은 증상을 일으키는 음식물의 성상, 증상의 경과,
심한 정도와 동반 증상 등의 기준으로 분류할 수 있다. 삼킴곤 란이 시작될 때부터 유동식과 고형식 모두에서 삼킴곤란이 발 생하였다면 식도 운동 질환일 가능성이 높다. 고형식에 대해 서만 삼킴곤란이 있으면 대개 식도 내강이 $13 \mathrm{~mm}$ 이하로 좁아진 협착 등이 원인 질환이다. 삼킴곤란이 발생하여 점점 심하게 되는 경우에 천천히 진행하면 소화성 협착(peptic stricture)일 수 있고, 빠르게 진행하면 식도암을 생각해야 한 다. ${ }^{32}$ 간헐적으로 삼킴곤란이 발생한다면 식도고리나 식도막 일 수 있고, 식도이완불능증에서는 점점 더 심해지며, 식도하 부연축(distal esophageal spasm)에서는 간헐적이거나 비진 행성일 수 있다. 정신과적 문제가 있는 경우 증상을 심하게 호소할 수 있다. ${ }^{33}$

동반 증상의 유무를 확인하면 진단에 도움을 받는다. 가슴 쓰림, 체중감소, 토혈, 빈혈, 음식물의 역류와 호흡기 증상 등 을 확인해야 한다. 만성적인 가슴 쓰림이 동반되어 있으면 위 식도 역류 질환의 합병증인 미란성 식도염, 소화성 협착(peptic stricture), 식도선암 등을 의심해 보아야 한다. 고령의 남성에 서 심각한 체중감소가 동반되어 있으면 식도암의 가능성이 높 다. ${ }^{31}$

(2) 삼킴곤란 증상에 따른 감별진단

고형식에 대해서만 삼킴곤란이 있으면서 점점 심해지는 경 우는 식도협착과 식도암일 수 있다. 식도협착은 위산역류, 방 사선 조사 혹은 호산구성 식도염 등에 의하여 발생한다. 위산 역류에 의한 소화성 협착은 미란성 식도염의 치유 과정에서 발생하며, 대부분 식도위 접합부 근처에 생긴다. 대개 고령의 남성에서 오랜 기간의 역류 증상이 있는 경우가 많다. ${ }^{34}$ 식도 협착은 식도내로 위산의 역류가 증가하는 질환인 전신경화증 (systemic sclerosis), Zollinger-Ellison 증후군, 코위관 삽관,

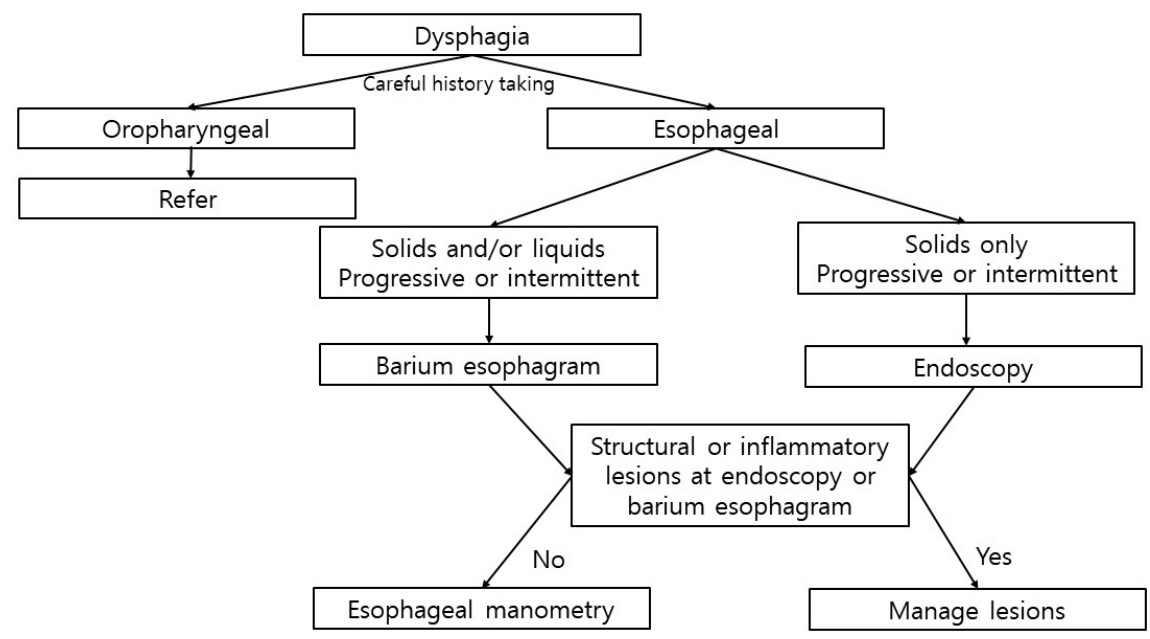

Fig. 1. Suggested approach to the patient with dysphagia (adapted from Liu et al. ${ }^{2}$ ). 
Heller 근절개술과 경구식도근절개술(peroral esophageal) 등에 의하여 발생되기도 한다. 드문 원인으로는 부식제에 의 한 식도 손상, 식도나 후두의 수술, 약제에 의한 식도 손상 등이 있다. 식도암은 삼킴곤란이 빠르게 진행하여 처음에는 고형식만 증상을 유발하다가 유동식도 점점 먹기 힘들어 진 다. 식도암은 또 흥통, 연하통, 빈혈, 식욕감퇴와 심각한 체중 감소 등이 동반된다.

고형식에 대해서만 삼킴곤란이 있으면서 간헐적인 증상이 있는 경우는 호산구성 식도염, 식도고리나 식도막과 혈관 이상 등이 있다. 호산구성 식도염은 삼킴곤란을 호소하는 환자의 내시경 검사에서 $15 \%$ 까지 진단된다고 서구에서 보고되었으 나, ${ }^{21,35,36}$ 아직 우리나라에서는 드문 것 같다. ${ }^{37}$ 식도고리와 식도 막은 단발성 혹은 다발성으로 발생할 수 있는데 식도고리는 대부분 평활한 표면을 가진 점막 구조이고 식도위 접합부에 위치하면서 길이는 $4 \mathrm{~mm}$ 미만이다. ${ }^{38}$ 식도막은 식도 내강내로 돌출한 얇은 점막 주름이며 경부 식도 전측에 가장 흔히 발생한 다. 식도막과 철결핍성 빈혈이 동반되어 있는 Plummer-Vinson 증후군은 우리나라에서 드물게 보고된다. ${ }^{39}$ 혈관 이상은 식도를 눌러서 삼킴곤란을 초래할 수 있으나 대단히 드물다. ${ }^{40,41}$

유동식에 대해서만 삼킴곤란이 있거나 유동식과 고형식에 대하여 삼킴곤란이 있는 경우는 식도이완불능증, 하부식도연 축과 과수축 식도 등의 식도 운동 질환과 기능성 삼킴곤란 (functional dysphagia)이 있다. 식도이완불능증에서 고형식 과 유동식에 대하여 점점 더 심해지는 삼킴곤란과 소화되지 않은 음식 혹은 침 등의 역류가 가장 흔하며 흉통, 가슴 쓰림, 트림 장애 등이 드물게 나타난다. 하부식도연축과 jackhammer 식도 환자에서는 고형식과 유동식에 대하여 간헐적, 비진행성 삼킴곤란과 흥통을 호소할 수 있다. ${ }^{42}$ 식도위 접합부 출구 폐색(esophagogastric junction outflow obstruction) 과 무수축(absent contractility)에서도 고형식과 유동식에 대 한 지속적 혹은 간헐적 삼킴곤란이 발생할 수 있다. ${ }^{31}$ 기능성 삼킴곤란은 고형식과 유동식에 대하여 삼킴곤란이 있으면서 증상의 원인이 되는 식도 점막 질환이나 구조적 이상, 위식도 역류 질환이나 호산구성 식도염, 주요 식도 운동 질환 등이 없을 때로 정의되며 삼킴곤란은 간헐적이거나 매 식사 시마다 발생할 수 있다. ${ }^{5}$ 삼킴곤란과 연하통이 동시에 발생하는 경우 는 감염성 식도염과 약제 유발성 식도염 등이 있고, 드물게 역류성 식도염과 크론병의 식도 침범 등이 있다.

\section{2) 검사}

자세한 병력청취 후 삼킴곤란의 원인을 알기 위한 검사를 시행하게 된다. 구인두 삼킴곤란이 의심되면 병상 삼킴 검사 들(bedside swallowing tests) ${ }^{30}$ 을 시행하여 구인두 삼킴곤 란이 맞는지 먼저 확인한다. 확진과 치료에 도움을 받기 위하
여 비디오 투시장치 삼킴 검사 ${ }^{43}$ 나 fiberoptic endoscopic swallowing study ${ }^{44}$ 를 시행한다.

50세 미만에서 경고 증상이 없으면서 삼킴곤란과 함께 전 형적인 위식도 역류 증상을 호소하면 먼저 고용량의 프로톤펌 프저해제를 4주간 투여하여 증상이 완전히 소실되지 않으면 검사를 시행한다. ${ }^{2}$ 우리나라에서는 이러한 서구의 가이드라인 을 그대로 따르는 데 신중해야 한다. 식도 삼킴곤란이 의심되 고 고형식과 유동식에 대하여 모두 삼킴곤란이 있는 경우에 식도 운동 질환을 염두에 두고 우선 식도조영술을 시행하고, 고형식에 대해서만 삼킴곤란이 있는 경우는 식도고리, 호산구 성 식도염, 위식도 역류 질환과 식도암 등의 가능성을 생각하 고 위 내시경을 우선 시행하게 된다. 미국의 한 연구에서 삼킴 곤란 환자 1,649 명에서 위 내시경 결과를 후향적으로 분석한 결과 $4 \%$ 에서 식도암이 진단되었고, $54 \%$ 에서 삼킴곤란의 원 인 질환이 발견되었다. ${ }^{45}$ 위 내시경에서 정상 소견이지만 여전 히 식도 고리나 식도 외부 압박 등의 기계적 폐색이 의심되는 경우는 식도조영술을 시행한다. 식도 운동 질환이 의심되거나 위 내시경에서 정상 소견을 보이는 삼킴곤란 환자에서는 반드 시 식도 내압 검사를 시행해야 한다.

\section{결 론}

삼킴곤란은 구인두 삼킴곤란과 식도 삼킴곤란으로 분류할 수 있다. 삼킴곤란을 호소하는 환자에서 우선적으로 구인두 삼킴곤란과 식도 삼킴곤란을 감별하는 것이 중요하다. 구인두 삼킴곤란 환자는 흡인과 흡인성 폐렴의 발생 가능성이 높기 때문에 삼킴곤란을 호소하는 경우에 초기에 정확한 진단을 해 야 한다. 구인두 삼킴곤란 환자는 삼킴의 시작에 어려움을 느 끼면서 삼킴 시 기침, 기도폐쇄, 코인두 역류, 흡인과 인두 내 남아 있는 음식의 느낌 등을 호소할 수 있다. 식도 삼킴곤란 환자는 삼킴 시작 수초 후에 삼키기 어렵다고 하며 먹은 음식 이 식도에 정체되어 있다고 한다. 삼킴곤란은 비교적 흔한 증 상으로 보고되고 있으며 우리나라에서도 증가하는 경향을 보 이고 있다. 식도 삼킴곤란은 삼킴곤란을 초래하는 음식이 고 형식, 유동식, 혹은 모두인지, 증상이 점점 심해지는지 혹은 간헐적인지, 얼마나 심한지, 체중감소, 가슴 쓰림 혹은 역류 등의 동반 증상이 있는지 등을 분석하여 원인 진단을 한다. 병력청취와 더불어 원인 진단을 위하여 진단적 검사를 시행한 다. 식도 운동 질환이 의심되면 우선 식도조영술을 시행하고 구조적 이상이 의심되면 위 내시경을 먼저 시행한다. 위 내시 경에서 정상 소견이지만 여전히 식도의 기계적 폐색이 의심되 는 경우는 식도조영술을 시행한다. 식도 운동 질환이 의심되 거나 위 내시경에서 정상 소견을 보이는 삼킴곤란 환자에서는 반드시 식도 내압 검사를 시행해야 한다. 


\section{REFERENCES}

1. Cho SY, Choung RS, Saito YA, et al. Prevalence and risk factors for dysphagia: a USA community study. Neurogastroenterol Motil 2015;27:212-219.

2. Liu LWC, Andrews CN, Armstrong D, et al. Clinical practice guidelines for the assessment of uninvestigated esophageal dysphagia. J Can Assoc Gastroenterol 2018;1:5-19.

3. Shamburek RD, Farrar JT. Disorders of the digestive system in the elderly. N Engl J Med 1990;322:438-443.

4. Tawil J, Fass R. Globus: current concepts and dilemmas. J Clin Gastroenterol 2018;52:845-852.

5. Aziz Q, Fass R, Gyawali CP, et al. Esophageal disorders. Gastroenterology 2016;150:1368-1379.

6. Gretarsdottir HM, Jonasson JG, Björnsson ES. Etiology and management of esophageal food impaction: a population based study. Scand J Gastroenterol 2015;50:513-518.

7. Sperry SL, Crockett SD, Miller CB, Shaheen NJ, Dellon ES. Esophageal foreign-body impactions: epidemiology, time trends, and the impact of the increasing prevalence of eosinophilic esophagitis. Gastrointest Endosc 2011;74:985-991.

8. Mann G, Hankey GJ, Cameron D. Swallowing function after stroke: prognosis and prognostic factors at 6 months. Stroke 1999;30:744-748.

9. Finestone HM, Greene-Finestone LS. Rehabilitation medicine: 2 . Diagnosis of dysphagia and its nutritional management for stroke patients. CMAJ 2003;169:1041-1044.

10. Lindgren S, Janzon L. Prevalence of swallowing complaints and clinical findings among 50-79-year-old men and women in an urban population. Dysphagia 1991;6:187-192.

11. Tibbling L, Gustafsson B. Dysphagia and its consequences in the elderly. Dysphagia 1991;6:200-202.

12. Cook IJ, Kahrilas PJ. AGA technical review on management of oropharyngeal dysphagia. Gastroenterology 1999;116:455-478.

13. Shanley C, O'Loughlin G. Dysphagia among nursing home residents: an assessment and management protocol. J Gerontol Nurs 2000;26:35-48.

14. Talley NJ, Weaver AL, Zinsmeister AR, Melton $L$ 3rd. Onset and disappearance of gastrointestinal symptoms and functional gastrointestinal disorders. Am J Epidemiol 1992;136:165-177.

15. Park YH, Han HR, Oh BM, et al. Prevalence and associated factors of dysphagia in nursing home residents. Geriatr Nurs 2013;34: 212-217.

16. Lee B, Lim HS. Prevalence and medical cost under malnutrition in dysphagia patients of Korea: based on health insurance review \& assessment service (HIRA) data. J Korean Dysphagia Soc 2020;10:97-106.

17. Roden DF, Altman KW. Causes of dysphagia among different age groups: a systematic review of the literature. Otolaryngol Clin North Am 2013;46:965-987.

18. Hinchey JA, Shephard T, Furie K, et al. Formal dysphagia screening protocols prevent pneumonia. Stroke 2005;36:1972-1976.

19. Donovan NJ, Daniels SK, Edmiaston J, et al. Dysphagia screening: state of the art: invitational conference proceeding from the State-of-the-Art Nursing Symposium, International Stroke Conference 2012. Stroke 2013;44:e24-e31.
20. Kalf JG, de Swart BJ, Bloem BR, Munneke M. Prevalence of oropharyngeal dysphagia in Parkinson's disease: a meta-analysis. Parkinsonism Relat Disord 2012;18:311-315.

21. Kidambi T, Toto E, Ho N, Taft T, Hirano I. Temporal trends in the relative prevalence of dysphagia etiologies from 1999-2009. World J Gastroenterol 2012;18:4335-4341.

22. Zhang HZ, Jin GF, Shen HB. Epidemiologic differences in esophageal cancer between Asian and Western populations. Chin J Cancer 2012;31:281-286.

23. Ronkainen J, Agréus L. Epidemiology of reflux symptoms and GORD. Best Pract Res Clin Gastroenterol 2013;27:325-337.

24. Almirall J, Rofes L, Serra-Prat M, et al. Oropharyngeal dysphagia is a risk factor for community-acquired pneumonia in the elderly. Eur Respir J 2013;41:923-928.

25. Martino R, Foley N, Bhogal S, Diamant N, Speechley M, Teasell R. Dysphagia after stroke: incidence, diagnosis, and pulmonary complications. Stroke 2005;36:2756-2763.

26. Smith DF, Ott DJ, Gelfand DW, Chen MY. Lower esophageal mucosal ring: correlation of referred symptoms with radiographic findings using a marshmallow bolus. AJR Am J Roentgenol 1998; 171:1361-1365.

27. Wilcox CM, Alexander LN, Clark WS. Localization of an obstructing esophageal lesion. Is the patient accurate?. Dig Dis Sci 1995;40:2192-2196.

28. Shaw SM, Martino R. The normal swallow: muscular and neurophysiological control. Otolaryngol Clin North Am 2013;46: 937-956.

29. Clavé P, Shaker R. Dysphagia: current reality and scope of the problem. Nat Rev Gastroenterol Hepatol 2015;12:259-270.

30. Kertscher B, Speyer R, Palmieri M, Plant C. Bedside screening to detect oropharyngeal dysphagia in patients with neurological disorders: an updated systematic review. Dysphagia 2014;29: 204-212.

31. Malagelada JR, Bazzoli F, Boeckxstaens G, et al. World gastroenterology organisation global guidelines: dysphagia--global guidelines and cascades update September 2014. J Clin Gastroenterol 2015;49:370-378.

32. Marks RD, Richter JE. Peptic strictures of the esophagus. Am J Gastroenterol 1993;88:1160-1173.

33. Carlson DA, Gyawali CP, Roman S, et al. Esophageal hypervigilance and visceral anxiety are contributors to symptom severity among patients evaluated with high-resolution esophageal manometry. Am J Gastroenterol 2020;115:367-375.

34. El-Serag HB, Sonnenberg A. Association of esophagitis and esophageal strictures with diseases treated with nonsteroidal anti-inflammatory drugs. Am J Gastroenterol 1997;92:52-56.

35. Prasad GA, Talley NJ, Romero Y, et al. Prevalence and predictive factors of eosinophilic esophagitis in patients presenting with dysphagia: a prospective study. Am J Gastroenterol 2007;102: 2627-2632.

36. Mackenzie SH, Go M, Chadwick B, et al. Eosinophilic oesophagitis in patients presenting with dysphagia-a prospective analysis. Aliment Pharmacol Ther 2008;28:1140-1146.

37. Kim SJ, Park MI, Kim GH, et al. Practice patterns for eosinophilic esophagitis patients in Busan and Gyeongnam: a Korean multicenter database study. J Neurogastroenterol Motil 2021;27: 
71-77.

38. Schatzki R. The lower esophageal ring. Long term follow-up of symptomatic and asymptomatic rings. Am J Roentgenol Radium Ther Nucl Med 1963;90:805-810.

39. Im HJ, Kim SE, Park Ml, et al. Gastric cancer accompanying Plummer-Vinson Syndrome. Korean J Helicobacter Up Gastrointest Res 2020;20:159-163.

40. De Luca L, Bergman JJ, Tytgat GN, Fockens P. EUS imaging of the arteria lusoria: case series and review. Gastrointest Endosc 2000;52:670-673.

41. Shin EJ, Kim HK, Kim JS, et al. A case of dysphagia lusoria caused by an aberrant right subclavian artery in an adolescent. Korean J Gastrointest Endosc 2008;36:213-218.
42. Clouse RE. Spastic disorders of the esophagus. Gastroenterologist 1997;5:112-127.

43. Jaffer NM, Ng E, Au FW, Steele CM. Fluoroscopic evaluation of oropharyngeal dysphagia: anatomic, technical, and common etiologic factors. AJR Am J Roentgenol 2015;204:49-58.

44. Dziewas R, Auf dem Brinke M, Birkmann U, et al. Safety and clinical impact of FEES - results of the FEES-registry. Neurol Res Pract 2019;1:16-23.

45. Varadarajulu S, Eloubeidi MA, Patel RS, et al. The yield and the predictors of esophageal pathology when upper endoscopy is used for the initial evaluation of dysphagia. Gastrointest Endosc 2005;61:804-808. 